\title{
Survei Kondisi Fisik Peserta Ekstrakurikuler Futsal Putra dan Putri Sekolah Menengah Atas
}

\author{
Bagus Aji Litardiansyah ${ }^{1 \star}$, Eko Hariyanto ${ }^{2}$ \\ 1,2Jurusan Pendidikan Jasmani Kesehatan dan Rekreasi, Fakultas IImu Keolahragaan, \\ Universitas Negeri Malang, Jalan Semarang No. 5, Malang, Jawa Timur, 65145, Indonesia \\ *Penulis koresponden: Blitardiansyah@gmail.com, 081230866983
}

\begin{abstract}
Futsal is a sport that requires excellent technique, tactics and physical condition. Likewise in futsal extracurricular activities of male and female high school students Ngoro Jombang need to pay attention to physical conditions, techniques and tactics that can have an impact on the appearance of participants. The purpose of this study was to determine the physical condition of futsal extracurricular members of male and female futsal Ngoro Jombang High Schools. The studyuses survey techniques with descrip tive research typein the form of quantitative data. Data collection is to use tests and measurements. The results of this study are male futsal extracurricular members of the "enough" speed category, "enough" agility category and "sufficient" category cardiorespiration endurance. While female futsal extracurricular participants in the speed categorywere "very lacking", the agility element in the "very less" category and cardiorespiration endurance in the "veryless" category. In the formula for categorizing male futsal extracurricular participants in the "enough" category and female futsal extracurricular participants in the "enough" category. It can be concluded that the futsal extracurricular members of the Ngoro Jombang Public High School male and female students were in the adequate physical condition category.
\end{abstract}

Keyword: physical condition; futsal; extracurricular

\begin{abstract}
Abstrak: Futsal merupakan olahraga yang sangat membutuhkan teknik, taktik dan kondisi fisik prima. Demikian juga pada kegiatan ekstrakurikuler futsal putra dan putri SMA Negeri Ngoro Jombang perlu memperhatikan kondisi fisik, teknik dan taktik yang dapat memberikan dampak pada penampilan peserta. Tujuan dalam penelitian ini yaitu mengetahui kondisi fisik peserta ekstrakurikuler futsal putra dan putri SMA Negeri Ngoro Jombang. Penelitian menggunakan teknik survei dengan jenis penelitian deskriptif dalam bentuk data kuantitatif. Pengumpulan data yaitu menggunakan tes dan pengukuran. Hasil penelitian ini yaitu peserta ekstrakurikuler futsal putra unsur kecepatan kategori "cukup", unsur kelincahan kategori "cukup" dan unsur daya tahan kardiorespirasi kategori "cukup". Sedangkan peserta ekstrakurikuler futsal putri unsur kecepatan kategori "sangat kurang", unsur kelincahan kategori "sangat kurang" dan daya tahan kardiorespirasi kategori "sangat kurang". Dalam rumus pengkategorian peserta ekstrakurikuler futsal putra kategori "cukup" dan peserta ekstrakurikuler futsal putri kategori "cukup". Dapat disimpulkan bahwa peserta ekstrakurikuler futsal putra dan putri SMA Negeri Ngoro Jombang dalam kondisi fisik kategori cukup.
\end{abstract}

Kata kunci: kondisi fisik; futsal; ekstrakurikuler 


\section{PENDAHULUAN}

Olahraga merupakan komponen terpenting dalam perkembangan hidup manusia untuk melakukan aktivitas setiap hari. Faktor yang menyebabkan manusia mengabaikan pentingnya olahraga, yaitu kesibukan aktivitas pekerjaan yang padat. Kurangnya memanfaatkan waktu luang yang menyebabkan kondisi fisik manusia semakin menurun. Olahraga sebagai kebutuhan dasar manusia untuk memenuhi kebutuhan jasmani dalam menentukan kualitas gerak dan kualitas hidup (Hariadi, 2017:1). Olahraga memiliki beberapa manfaat, yaitu meningkatnya daya tahan tubuh, fungsi otak meningkat, stress hilang dan menurunnya kolesterol (Pane 2015). Manfaat melakukan latihan aerobik dapat meningkatkan kebugaran fisik (Palar, Wongkar, and Ticoalu 2015).

Saat ini olahraga yang banyak digemari di Indonesia adalah futsal. Olahraga futsal mayoritas banyak digemari kalangan usia muda. Tidak hanya digemari kaum pria, bahkan diminati oleh kaum wanita (Ashari and Adi 2019). Olahraga futsal yaitu salah satu olahraga yang berbentuk permainan menggunakan bola yang idealnya dilakukan pada suatu ruangan atau indoor. Permainan futsal tidak jauh dengan sepakbola hanya yang membedakan adalah ukuran lapangan, ukuran bola yang digunakan, ukuran gawang, waktu permainan dan jumlah pemain inti berjumlah lima orang dengan beberapa pemain cadangan serta peraturan permainan. Dalam futsal terdapat komponen yang harus diperhatikan dalam latihan maupun bertanding, yaitu teknik, fisik, taktik dan mental. Komponen-komponen tersebut sangat berpengaruh pada peningkatan prestasi atlet futsal.

Olahraga futsal memiliki taktik, teknik khusus dan kondisi fisik yang berbeda dengan olahraga lain. Karakteristik yang dibutuhkan, yaitu kecepatan bergerak, kekuatan fisik serta kelincahan bergerak dengan waktu yang dominan lama. Sehingga pemain harus dominan memiliki komponen daya tahan, kekuatan dan kecepatan (Amiq, 2014:3).

Pencapaian prestasi yang tidak optimal dapat dipengaruhi oleh kesalahan prinsip beban berlebih serta peran fisiologi olahraga dapat membantu meningkatkan prestasi atlet (Anggriawan 2015). Faktor-faktor tersebut sangat penting bagi seorang atlet dalam meningkatkan prestasi. Faktor frekuensi latihan sangat berpengaruh dalam upaya pencapaian prestasi yang harus diperhatikan oleh pelatih. Selain itu, faktor pelatih sangat berpengaruh pada kejiwaan anak latihnya. Pelatih harus tetap tampil prima dengan memiliki kebugaran jasmani dan kesehatan mental di lapangan pada saat latihan maupun pertandingan. Selain itu di dalam olahraga untuk mengacu pada prestasi untuk frekuensi latihan yaitu 3-6 kali dalam 1 minggu selain itu, olahraga untuk mengacu pada kebugaran atau kesehatan untuk frekuensi latihan yaitu 1-3 kali dalam 1 minggu (Rahayu, 2017:16) .

Pada umumnya cabang olahraga futsal salah satu olahraga yang diharuskan memiliki mental, ketahanan, stamina serta strategi serta kondisi fisik prima, karena olahraga futsal mempunyai karakteristik permainan gerak cepat, teknik serta kondisi fisik yang kuat. Kondisi fisik atlet dapat dilatih dan ditingkatkan saat berlatih. Terlebih olahraga futsal terdapat kontak fisik dan gerak berpindah dengan cukup cepat. Intensitas latihan yang sistematis dan teratur dengan beban meningkat maka kondisi fisik atlet akan bertambah dengan sendirinya (Amiq, 2014:13-14). Olahraga futsal menuntut semua pemain memiliki kondisi fisik yang prima sebagai penunjang prestasi. Sehebat apapun teknik dan taktik yang dimiliki seorang pemain jika kondisi fisik yang buruk sangat berbeda dibandingkan pemain yang memiliki kemampuan teknik, taktik, strategi dan terutama kondisi fisik yang baik atau prima, maka jelas peranan kondisi fisik sangat berpengaruh kepada atlet saat bermain futsal.

Kondisi fisik di dalam olahraga futsal sangat dibutuhkan komponen kesegaran jasmani yang terakait dengan kesehatan dan kemampuan gerak sebagai ketahanan tubuh. Beberapa komponen kesegaran jasmani yang berkaitan dengan kondisi fisik, yaitu kekuatan, kelentukan, komposisi tubuh, daya tahan (kardiorespirasi dan otot), kecepatan, power, kelincahan, keseimbangan, koordinasi dan kecepatan reaksi (Nurhasan, 2011:13-17) . Seorang atlet futsal sangat membutuhkan komponen kebugaran jasmani di dalam menunjang kondisi fisiknya. Untuk mengetahui unsur kondisi fisik tersebut penting dilakukan tes dan pengukuran pada masingmasing unsur tersebut.

Perkembangan olahraga futsal dibuktikan dengan banyaknya klub-klub futsal di kota maupun di daerah yang menyediakan penyewaan lapangan futsal serta diadakannya ekstrakurikuler futsal bagi siswa putra dan putri baik Sekolah Dasar (SD), Sekolah Menengah Pertama (SMP), Sekolah Menengah Atas (SMA) bahkan kalangan mahasiswa. Kompetisi futsal biasanya didominasi tim putra, tetapi kini sudah dimulai kompetisi futsal tim putri di tingkat daerah maupun nasional. Beberapa Sekolah Menengah Atas di Indonesia mulai terpacu membuat tim futsal putra dan putri melalui kegiatan ekstrakurikuler. Banyak pihak sekolah menjadikan futsal 
sebagai kegiatan ekstrakurikuler. Dalam kegiatan ekstrakurikuler terdapat hubungan dengan pendidikan karakter siswa sebagai pengejawantahan antara pengetahuan yang diperoleh dengan sikap dan keterampilan (Dahliyana 2017). Manajemen ekstrakurikuler sangat penting dalam meningkatkan mutu sekolah, baik mengembangkan bidang akademik maupun non akademik meliputi perencanaan ekstrakurikuler, pelaksanaan ekstrakurikuler serta evaluasi ekstrakurikuler dengan dukugan sarana prasarana dan dana serta jadwal yang tepat (Ubaidah 2014).

Kegiatan ekstrakurikuler dapat diartikan kegiatan berbentuk non-akademik maupun akademik yang dilaksanakan dalam naungan sekolah di luar waktu kelas normal dan bukan bagian dari kurikulum (Bartkus et al. 2012). Dalam kegiatan ekstrakurikuler dapat dibedakan menjadi dua jenis, yaitu non olahraga dan olahraga. Kegiatan ekstrakurikuler non olahraga seperti ekstrakurikuler pramuka, paskibra, pecinta alam dan sebagainya, sedangkan ekstrakurikuler olahraga seperti ekstrakurikuler sepakbola, basket, futsal, bulutangkis dan sebagainya. Pada dasarnya kegiatan ekstrakurikuler memiliki tujuan yang sama yaitu untuk mengembangkan kedisiplinan, kemampuan dan minat peserta di beberapa Sekolah (Mirfa'ani and Nurrochmah 2020).

SMA Negeri Ngoro Jombang salah satu sekolah yang berakreditasi A yang menjaring peserta didik baru melalui jalur prestasi non-akademik maupun jalur prestasi akademik. Sekolah Menengah Atas (SMA) Negeri Ngoro Jombang merupakan salah satu Sekolah Menengah Atas (SMA) yang terletak di Kecamatan Ngoro Kabupaten Jombang yang memiliki kegiatan ekstrakurikuler olahraga dengan berbagai bidang olahraga, yaitu olahraga futsal berjumlah 50 peserta, olahraga bolavoli berjumlah 11 peserta, olahraga kempo berjumlah 15 peserta dan olahraga pencak silat asad berjumlah 12 peserta. Diantara sajian tersebut peneliti tertarik mengkaji jenis olahraga futsal. Alasan peneliti memilih ekstrakurikuler futsal karena cukup banyak peserta yang meminati. Jumlah peserta yang mengikuti ekstrakurikuler futsal sebanyak 31 peserta putra dan 19 peserta putri. Peserta ekstrakurikuler futsal putra memiliki jadwal latihan yaitu 2 pertemuan dalam 1 minggu di hari Senin dan Rabu, sedangkan peserta ekstrakurikuler putri memiliki jadwal latihan yaitu 2 pertemuan dalam 1 minggu di hari Selasa dan Kamis. Latihan ekstrakurikuler futsal dimulai pada pukul 15.30-17.00 WIB di Lapangan basket SMA Negeri Ngoro Jombang.

Berdasarkan pengamatan dan wawancara kepada pelatih saat latihan ekstrakurikuler putra dan putri SMA Negeri Ngoro Jombang. Peneliti menyimpulkan bahwa lapangan yang relatif kecil daripada lapangan sepakbola yang menuntut peserta ekstrakurikuler futsal bergerak dengan cepat, sehingga peserta ekstrakurikuler futsal putra maupun putri membutuhkan kondisi fisik yang baik dan prima agar dapat bertanding maupun berlatih secara optimal. Namun pada kenyataannya peserta ekstrakurikuler futsal putra maupun putri terlihat mudah kelelahan dan sulit berpindah tempat yang menyebabkan latihan menjadi kurang optimal. Ekstrakurikuler futsal putra terbentuk pada tahun 2017 dan ekstrakurikuler futsal putri terbentuk pada tahun 2018. Diketahui bahwa pelatih belum memiliki lisensi kepelatihan dan hanya memberikan latihan berdasarkan pengalaman ketika masih aktif menjadi pemain. pelatih lebih terfokus memberikan latihan teknik dan taktik. Selain itu pelatih juga belum pernah melakukan tes kondisi fisik kepada semua peserta ekstrakurikuler futsal yang dapat dijadikan tolak ukur dalam taraf peningkatan fisik peserta ekstrakurikuler futsal putra dan putri. Kendala saat latihan, yaitu terbatasnya jam yang diberikan sekolah kepada pelatih, sehingga pelatih merasa belum maksimal dalam memberikan variasi latihan.

Terkait dengan hal yang telah diketahui tersebut peneliti ingin mengetahui tentang kondisi fisik peserta lebih lanjut. Untuk mengetahui perolehan data kondisi fisik peserta futsal bisa diketahui menggunakan tes pada fisik peserta berdasarkan tingkat kecepatan, kelincahan dan daya tahan kardiorespirasi. Berdasarkan latar belakang masalah, perlu dibuktikan secara ilmiah melalui sebuah penelitian yang berjudul "Survei Kondisi Fisik Peserta Ekstrakurikuler Futsal Putra dan Putri SMA Negeri Ngoro Jombang".

\section{METODE}

Penelitian menggunakan teknik survei dengan jenis penelitian deskriptif dalam bentuk data kuantitatif. Penelitian peserta ekstrakurikuler futsal putra dan putri SMA Negeri Ngoro Jombang Jombang dengan jumlah subjek 50 peserta. Teknik analisis data menggunakan statistik deskriptif berupa persentase.

Subjek penelitian ini yaitu peserta ekstrakurikuler futsal putra dan putri SMA Negeri Ngoro Jombang dengan jumlah 31 peserta putra dan 19 peserta putri. 
Instrumen tes yang digunakan adalah tes sprint 30 meter sebagai pengukur kecepatan, Illinois Agility Run Test sebagai pengukur kelincahan dan Multistage Fitness Test sebagai pengukur daya tahan.

Setelah data tes dan pengukuran terkumpul langkah selanjutnya penilaian dilakukan dengan melihat norma tes sesuai variabel tes. Hasil data diperoleh rata-rata selanjutnya dipersentasekan dengan merujuk pada tabel norma untuk mengetahui kategori setiap variabel tes. Selanjutnya data dirubah menjadi ke dalam T-score, kemudian data T-score dirubah menggunakan rumus pengkategorian untuk menentukan kategori keseluruhan variabel tes.

HASIL

Berdasarkan hasil analisis data deskriptif kuatitatif sebagai subjek penelitian diperoleh data kasar dari pelaksanaan hasil tes, selanjutnya penilaian dilakukan dengan melihat norma tes sesuai variabel tes. Hasil data diperoleh rata-rata selanjutnya data dipersentasekan menggunakan tabel norma untuk megetahui kategori. Selanjutnya data dirubah ke dalam T-score, kemudian data T-score dirubah menggunakan rumus pengakategorian untuk menentukan kategori keseluruhan variabel tes. Hasil tes dapat dikategorikan setiap variabel tes sebagai berikut.

Komponen Kecepatan Tes Sprint 30 Meter Untuk Putra

Tabel 1. Persentase Komponen Kecepatan Tes Sprint 30 Meter

\begin{tabular}{clcc}
\hline $\begin{array}{c}\text { Interval } \\
\text { (detik) }\end{array}$ & \multicolumn{1}{c}{ Kategori } & Frekuensi & Persentase (\%) \\
\hline$<4,0$ & Sangat Baik & 0 & 0 \\
$\mathbf{4 , 0 - 4 , 2}$ & Baik & 9 & 29 \\
$\mathbf{4 , 3 - 4 , 4}$ & Cukup & 15 & 48 \\
$\mathbf{4 , 5 - 4 , 6}$ & Kurang & 4 & 13 \\
$>\mathbf{4 , 6}$ & Sangat Kurang & 3 & 10 \\
\hline
\end{tabular}

Komponen Kelincahan Illinois Agility Run Test Untuk Putra

Tabel 2. Persentase Komponen Kelincahan Illinois Agility Run Test

\begin{tabular}{clcc}
\hline $\begin{array}{c}\text { Interval } \\
\text { (detik) }\end{array}$ & \multicolumn{1}{c}{ Kategori } & Frekuensi & Persentase (\%) \\
\hline$<\mathbf{1 5 , 2}$ & Sangat Baik & 0 & 0 \\
$\mathbf{1 5 , 2 - 1 6 , 1}$ & Baik & 1 & 3 \\
$\mathbf{1 6 , 2 - 1 8 , 1}$ & Cukup & 11 & 35 \\
$\mathbf{1 8 , 2 - 1 8 , 3}$ & Kurang & 9 & 29 \\
$\mathbf{> 1 8 , 3}$ & Sangat Kurang & 10 & 32 \\
\hline
\end{tabular}

Komponen Daya Tahan Kardiorespirasi Multistage Fitness Test Untuk Putra

Tabel 3. Persentase Komponen Daya Tahan Kardiorespirasi Multistage Fitness Test

\begin{tabular}{clcc}
\hline $\begin{array}{c}\text { Interval } \\
(\mathbf{m l} / \mathbf{k g} / \mathbf{m i n})\end{array}$ & \multicolumn{1}{c}{ Kategori } & Frekuensi & Persentase (\%) \\
\hline $\mathbf{5 5 5 , 9}$ & Unggul & 0 & 0 \\
$\mathbf{5 1 , 0 - 5 5 , 9}$ & Sangat Baik & 0 & 0 \\
$\mathbf{4 5 , 2 - 5 0 , 9}$ & Baik & 1 & 3 \\
$\mathbf{3 8 , 4 - 4 5 , 1}$ & Cukup & 13 & 42 \\
$\mathbf{3 5 , 0 - 3 8 , 3}$ & Kurang & 7 & 23 \\
$<\mathbf{3 5 , 0}$ & Sangat Kurang & 10 & 32 \\
\hline
\end{tabular}


Komponen Kecepatan Tes Sprint 30 Meter Untuk Putri

Tabel 4. Persentase Komponen Kecepatan Tes Sprint 30 Meter

\begin{tabular}{clcc}
\hline $\begin{array}{c}\text { Interval } \\
\text { (detik) }\end{array}$ & \multicolumn{1}{c}{ Kategori } & Frekuensi & Persentase (\%) \\
\hline$<4,5$ & Sangat Baik & 0 & 0 \\
$\mathbf{4 , 5 - 4 , 6}$ & Baik & 0 & 0 \\
$\mathbf{4 , 7 - 4 , 8}$ & Cukup & 3 & 16 \\
$\mathbf{4 , 9 - 5 , 0}$ & Kurang & 1 & 5 \\
$>\mathbf{5 , 0}$ & Sangat Kurang & 15 & 79 \\
\hline
\end{tabular}

Komponen Kelincahan IIlionist Agility Run Test Untuk Putri

Tabel 5. Persentase Komponen Kelincahan Illinoist Agility Run Test

\begin{tabular}{clcc}
\hline $\begin{array}{c}\text { Interval } \\
\text { (detik) }\end{array}$ & \multicolumn{1}{c}{ Kategori } & Frekuensi & Presentase (\%) \\
\hline$<\mathbf{1 7 , 0}$ & Sangat Baik & 0 & 0 \\
$\mathbf{1 7 , 0 - 1 7 , 9}$ & Baik & 0 & 0 \\
$\mathbf{1 8 , 0 - 2 1 , 7}$ & Cukup & 2 & 11 \\
$\mathbf{2 1 , 8 - 2 3 , 0}$ & Kurang & 0 & 0 \\
$\mathbf{> 2 3 , 0}$ & Sangat Kurang & 17 & 89 \\
\hline
\end{tabular}

Komponen Daya Tahan Kardiorespirasi Multistage Fitness Test Untuk Putri

Tabel 6. Persentase Komponen Daya Tahan Kardiorespirasi Multistage Fitness Test

\begin{tabular}{clcc}
\hline $\begin{array}{c}\text { Interval } \\
(\mathbf{m l} / \mathbf{k g} / \mathbf{m i n})\end{array}$ & \multicolumn{1}{c}{ Kategori } & Frekuensi & Presentase (\%) \\
\hline$>\mathbf{4 1 , 9}$ & Unggul & 0 & 0 \\
$\mathbf{3 9 , 0 - 4 1 , 9}$ & Sangat Baik & 0 & 0 \\
$\mathbf{3 5 , 0 - 3 8 , 9}$ & Baik & 0 & 0 \\
$\mathbf{3 1 , 0 - 3 4 , 9}$ & Cukup & 0 & 0 \\
$\mathbf{2 5 , 0 - 3 0 , 9}$ & Kurang & 1 & 5 \\
$<\mathbf{2 5 , 0}$ & Sangat Kurang & 18 & 95 \\
\hline
\end{tabular}

Dari ketiga unsur kondisi fisik yang telah diteliti untuk peserta ekstrakurikuler futsal putra, yaitu unsur kelincahan dalam kategori cukup, unsur kelincahan dalam kategori cukup dan unsur daya tahan kardiorespirasi cukup. Sedangkan peserta ekstrakurikuler futsal putri, yaitu unsur kecepatan dominan pada kategori sangat kurang, unsur kelincahan dominan pada kategori sangat kurang serta unsur daya tahan kardiorespirasi dominan pada kategori sangat kurang. Data kemudian dirubah ke rumus T-score setelah hasil T-score diketahui dimasukkan ke dalam rumus pengkategori untuk menentukan kategori kondisi fisik peserta ekstrakurikuler putra dan putri SMA Negeri Ngoro Jombang keseluruhan variabel tes. Berikut dapat dilihat pada tabel hasil rumus pengkategorian kondisi fisik peserta ekstrakurikuler futsal putra dan putri SMA Negeri Ngoro Jombang. 


\section{Hasil Analisis Deskriptif Persentase Kondisi Fisik Peserta Ekstrakurikuler Futsal Putra SMA Negeri Ngoro Jombang}

Tabel 7. Hasil Analisis Deskriptif Persentase Kondisi Fisik Peserta Ekstrakurikuler Futsal Putra SMA Negeri Ngoro Jombang

\begin{tabular}{cccc}
\hline Rentang Skor & Kategori & Jumlah & Persentase \\
\hline $\mathbf{X} \geq \mathbf{1 7 3 , 5 3 0}$ & Sangat Baik & 1 & $3 \%$ \\
$\mathbf{1 5 7 , 8 4 3} \leq \mathbf{X} \leq \mathbf{1 7 3 , 5 3 0}$ & Baik & 9 & $29 \%$ \\
$\mathbf{1 4 2 , 1 5 6} \leq \mathbf{X} \leq \mathbf{1 5 7 , 8 4 3}$ & Cukup & 13 & $42 \%$ \\
$\mathbf{1 2 6 , 4 6 9} \leq \mathbf{X} \leq \mathbf{1 4 2 , 1 5 6}$ & Kurang & 3 & $10 \%$ \\
$\mathbf{X} \leq \mathbf{1 2 6 , 4 6 9}$ & Sangat Kurang & 5 & $16 \%$ \\
\hline
\end{tabular}

\section{Hasil Analisis Deskriptif Persentase Kondisi Fisik Peserta Ekstrakurikuler Futsal Putri SMA Negeri Ngoro Jombang}

Tabel 8. Hasil Analisis Deskriptif Persentase Kondisi Fisik Peserta Ekstrakurikuler Futsal Putri SMA Negeri Ngoro Jombang

\begin{tabular}{cccc}
\hline Rentang Skor & Kategori & Jumlah & Persetase \\
\hline $\mathbf{X} \geq \mathbf{1 7 2 , 4 5 5}$ & Sangat Baik & 1 & $5 \%$ \\
$\mathbf{1 5 7 , 4 8 5} \leq X \leq \mathbf{1 7 2 , 4 5 5}$ & Baik & 5 & $26 \%$ \\
$\mathbf{1 4 2 , 5 1 4} \leq X \leq \mathbf{1 5 7 , 4 8 5}$ & Cukup & 9 & $47 \%$ \\
$\mathbf{1 2 7 , 5 4 4} \leq X \leq \mathbf{1 4 2 , 5 1 4}$ & Kurang & 2 & $11 \%$ \\
$\mathbf{X} \leq \mathbf{1 2 7 , 5 4 4}$ & Sangat Kurang & 2 & $11 \%$ \\
\hline
\end{tabular}

\section{PEMBAHASAN}

Berdasarkan hasil analisis deskriptif kuantatif peserta ekstrakurikuler futsal putra SMA Negeri Ngoro Jombang unsur kecepatan dalam kategori "cukup" dan peserta ekstrakurikuler futsal putri SMA Negeri Ngoro Jombang dalam kategori "sangat kurang". Melihat rendahnya unsur kecepatan karena kurangnya latihan fisik dan frekuensi latihan yang sistematis. Unsur kecepatan sangat berpengaruh pada permainan futsal, sesuai karakteristik permainan futsal, seorang pemain diharuskan dapat melakukan pergerakan transisi yang cepat untuk berpindah posisi dan menggiring bola, sehingga unsur kecepatan dan kelincahan memiliki keterkaitan pada kemampuan seseorang dalam menggiring bola (Gunawan, Suherman, and Sudirjo 2016). Dalam taraf peningkatkan unsur kecepatan berlari pada peserta ekstrakurikuler futsal putra dan putri SMA Negeri Ngoro Jombang diperlukan latihan seperti lompat kijang cepat dan lompat kijang irama lambat, karena dengan menggunakan latihan jenis lompat kijang secara cepat dan lompat kijang irama secara lambat dapat digunakan sebagai latihan untuk taraf peningkatkan kecepatan berlari (Anon 2012). Selain itu meningkatkan unsur kecepatan menggunakan latihan kecepatan dengan bentuk lari cepat, yaitu latihan zig-zag mengitari tiang yang dapat meningkatkan kecepatan menggiring bola. Oleh karena itu terdapat pengaruh latihan kecepatan terhadap kecepatan menggiring bola (Matitaputty 2019).

Berdasarkan hasil analisis deskriptif kuantitatif peserta ekstrakurikuler futsal putra SMA Negeri Ngoro Jombang unsur kelincahan dalam kategori "cukup" dan peserta ekstrakurikuler futsal putri SMA Negeri Ngoro Jombang dalam kategori "sangat kurang". Permainan futsal dilakukan dengan bergerak secara cepat dengan lapangan lebih kecil dibandingkan olahraga sepakbola, pemain futsal diharuskan memiliki kelincahan yang baik, berguna untuk melewati lawan atau mengelabuhi lawan serta mengontrol bola dengan bergerak. Kelincahan memiliki hubungan dengan ketepatan terhadap kemampuan stop passing (Arwin 2017). Untuk meningkatkan unsur kelincahan peserta ekstrakurikuler futsal putra dan putri SMA Negeri Ngoro Jombang diperlukan latihan drill kelincahan menggunakan tiga cone, empat cone dan lima cone untuk peningkatkan 
kelincahan berlari (Diputra 2015). Selain itu meningkatkan unsur kelincahan menggunakan latihan kelincahan dengan bentuk ladder drill yang signifikan terhadap peningkatan kelincahan (Hadi, Hariyanto, and Amiq 2016).

Berdasarkan hasil analisis deskriptif kuantitatif peserta ekstrakurikuler futsal putra SMA Negeri Ngoro Jombang unsur daya tahan kardiorespirasi dalam kategori "cukup" dan peserta ekstrakurikuler futsal putri SMA Negeri Ngoro Jombang dalam kategori "sangat kurang". Permainan futsal yang sangat cepat, pemain diharuskan memiliki ketahanan fisik untuk selalu bergerak dari satu posisi ke posisi lain dengan waktu yang cukup lama. Sehingga pemain membutuhkan daya tahan kardiorespirasi yang tinggi. Oleh karena itu terdapat hubungan kapasitas vital paru paru-paru dengan daya tahan kardiorespirasi (Syahda, Damayanti, and Imanudin 2016). VO2max sangat berperan dalam menentukan besarnya upaya yang dirasakan pemain selama melakukan sesi pelatihan futsal (Milanez et al. 2011). Untuk meningkatkan daya tahan kardiorespirasi peserta ekstrakurikuler futsal diperlukan latihan seperti small sided games dalam meningkatkan VO2max (Puriana and Kurniawan 2019).

\section{Frekuensi Latihan}

Frekuensi latihan yang dilakukan pada peserta ekstrakurikuler futsal putra dan putri SMA Negeri Ngoro Jombang hanya dilakukan 2 kali dalam 1 minggu. Padahal untuk olahraga yang mengacu prestasi untuk frekuensi latihannya 3-6 kali dalam 1 minggu dan olahraga mengacu pada kebugaran untuk frekuensi latihannya 1-3 kali dalam 1 minggu (Rahayu, 2017:16). Melalui latihan fisik sangat berpengaruh pada frekuensi denyut nadi (Sandi 2016). Terdapat pengaruh intensitas latihan, durasi dan frekuensi dari respons fisiologis integratif terhadap latihan interval (Macinnis and Gibala 2017).

\section{Latihan Fisik}

Penampilan pemain dapat dilihat dari kondisi fisik yang baik atau prima dalam bermain futsal. Sedangkan pemain yang memiliki tingkat fisik yang rendah tentu dapat menunjukkan dampak buruk bagi pemain dalam segi teknik, taktik dan strategi. kondisi fisik yang baik dapat menunjang penampilan maupun prestasi pemain (Amiq, 2014:19-20). Berdasarkan hasil dari observasi yang sudah dilakukan, latihan yang terfokus pada teknik dan taktik, tidak banyak latihan fisik yang dilakukan. Bahkan kebanyakan pemain mudah kelelahan dan mengeluh. Kebugaran aerobik serta kemampuan melakukan tindakan intensitas tinggi secara berulang dapat berpengaruh pada beban latihan interval pemain futsal (Miloski et al. 2014). Banyak macam latihan fisik yang dapat dilakukan untuk meningkatkan kelincahan contohnya latihan tabata circuit untuk meningkatan kelincahan (Romdani and Agus Prianto 2018). Untuk meningkatkan kecepatan berlari menggunakan latihan interval training yang dapat meningkatkan kecepatan, karena terdapat pengaruh yang signifikan pada peningkatan kecepatan (Ihsan, Mentara, and Kamarudin 2017). Sedangkan untuk meningkatkan daya tahan kardiorespirasi dapat dilakukan menggunakan latihan lari 12 menit dan lari bolak balik serta latihan konvensional, karena terdapat pengaruh yang signifikan pada peningkatan daya tahan (Prayuda and Firmansyah 2017).

\section{KESIMPULAN}

Kondisi fisik peserta ekstrakurikuler putra putra dan putri SMA Negeri Ngoro Jombang dominan dalam kategori cukup. Untuk meningkatkan kondisi fisik peserta ekstrakurikuler futsal putra dan putri SMA Negeri Ngoro Jombang diantaranya frekuensi latihan secara baik dan sistematis.

\section{DAFTAR PUSTAKA}

Amiq, Fahrial. 2014. Futsal (Sejarah, Teknik Dasar, Persiapan Fisik, Strategi, Dan Peraturan Permainan). Malang: Universitas Negeri Malang.

Anggriawan, N. 2015. "Peran Fisiologi Olahraga Dalam Menunjang Prestasi." Jurnal Olahraga Prestasi 11(2):8-18.

Anon. 2012. "Pengaruh Latihan Lompat Kijang terhadap Kecepatan Lari." JSSF (Journal of Sport Science and Fitness).

Arwin, Hasbi. 2017. "Hubungan Ketepatan Dan Kelincahan Terhadap Kemampuan Stop Passing Olahraga 
Futsal Pada Siswa Sma Negeri 9 Banda Aceh." 3(3):189-95.

Ashari, Rahmat Fahmi, and Sapto Adi. 2019. "Pengembangan Model Latihan Menyerang Futsal Menggunakan Formasi 3-1." Sport Science and Health 1(2):110-15.

Bartkus, Kenneth R., Blake Nemelka, Mark Nemelka, and Phil Gardner. 2012. "Clarifying The Meaning Of Extracurricular Activity: A Literature Review Of Definitions." American Journal of Business Education 5(6):693-704.

Dahliyana, Asep. 2017. "Penguatan Pendidikan Karakter Melalui Kegiatan Ekstrakurikuler Di Sekolah." Jurnal Sosioreligi 15(1):54-64.

Diputra, Rahman. 2015. "Pengaruh Latihan Three Cone Drill, Four Cone Drill, Dan Five Cone Drillterhadap Kelincahan (Agility) Dan Kecepatan (Speed)." Jurnal Sportif 1(1):41-59.

Gunawan, Yusup Rochmat, Ayi Suherman, and Encep Sudirjo. 2016. "Hubungan Kecepatan Dan Kelincahan Terhadap Kemampuan Dribbling Bola Futsal Pada Atlet O2SN Kecamatan Sumedang Utara." Sportive 1(1):1-12.

Hadi, Firdaus Soffan, Eko Hariyanto, and Fahrial Amiq. 2016. "Pengaruh Latihan Ladder Drills Terhadap Peningkatan Kelincahan Siswa U-17 Di Persatuan Sepakbola Jajag Kabupaten Banyuwangi." Jurnal Pendidikan Jasmani 26(1):213-28.

Hariadi, Abdul Majid. 2017. Handal Tentang Futsal. Surabaya: PT. JePe Press Media Utama.

Ihsan, N. U. R., Hendrik Mentara, and Kamarudin. 2017. "Pengaruh Latihan Interval Training Terhadap Kecepatan Dalam Permainan Futsal Pada Atlet Orinity." Tadulako Journal Sport Sciences and Physical Education 6(1):54-65.

Macinnis, Martin J., and Martin J. Gibala. 2017. "Physiological Adaptations to Interval Training and the Role of Exercise Intensity." The Journal of Physiology 595(9):2915-30.

Matitaputty, Johanna. 2019. "Pengaruh Latihan Kecepatan Terhadap Kecepatan Menggiring Bola Pemain Futsal Junior Fc Patriot Penjaskesrek Unpatti Ambon." Jurnal IImiah Wahana Pendidikan 5(2):101-13.

Milanez, Vinícius F., Rafael E. Pedro, Alexandre Moreira, Daniel A. Boullosa, Fuad Salle-neto, and Fábio Y. Nakamura. 2011. "The Role of Aerobic Fitness on Session Rating of Perceived Exertion in Futsal Players." International Journal of Sport Physiology and Performance 6(3):358-66.

Miloski, Bernardo, Alexandre Moreira, Francine Caetano, De Andrade Nogueira, and Victor De Freitas. 2014. "Aerobic Fitness and the Ability to Perform High-Intensity Actions Repeatedly Can Affect the Futsal Player's Training Load." J Sportas Med Fitness 54(5):588-94.

Mirfa'ani, Nuril, and Siti Nurrochmah. 2020. "Survei Kemampuan Kondisi Fisik Peserta Kegiatan Ekstrakurikuler Pencak Silat Perisai Diri Di Sekolah Menengah Atas." Sport Scien 2(4):239-46.

Nurhasan. 2011. Tips Praktis Menjaga Kebugaran Jasmani. Gresik: Abil Pustaka.

Palar, Chrisly M., Djon Wongkar, and Shane H. R. Ticoalu. 2015. "Manfaat Latihan Olahraga Aerobik Terhadap Kebugaran Fisik Manusia." Jurnal E-Biomedik 3(1).

Pane, Bessy Sitorus. 2015. "Peranan Olahraga Dalam Meningkatkan Kesehatan." Jurnal Pengabdian Kepada Masyarakat 21(79):1-4.

Prayuda, Anggi Yuga, and Guntur Firmansyah. 2017. "Pengaruh Latihan Lari 12 Menit Dan Lari Bolak Balik Terhadap Peningkatan Daya Tahan VO2 Max." Jurnal Pendidikan Jasmani, Olahraga Dan Kesehatan 1(1):13-22.

Puriana, Ramadhany Hananto, and Doni Kurniawan. 2019. "Pengaruh Latihan Small Sided Games 3\3 Dan 4v4 Terhadap Peningkatan VO2max Atlet Futsal Di Lamongan." Jurnal Pendidikan Jasmani 2(1):18793.

Rahayu. 2017. Penataran Pelatih Olahraga Tingkat Muda. Jakarta: Koni Pusat.

Romdani, Sakir, and David Agus Prianto. 2018. "Pengaruh Latihan Latihan Tabata Circuit Training Terhadap Peningkatan Kelincahan Pada Pemain Futsal." Jurnal Prestasi Olahraga 1(4):1-5. 
Sandi, I. 2016. "Pengaruh Latihan Fisik Terhadap Frekuensi Denyut Nadi." Sport and Fitness Journal 4(2):16.

Syahda, IIman Alifa, Imas Damayanti, and Iman Imanudin. 2016. "Hubungan Kapasitas Vital Paru-Paru Dengan Daya Tahan Cardiorespiratory Pada Cabang Olahraga Sepak Bola." Jurnal Terapan IImu Keolahragaan 1(1):24-28.

Ubaidah, Siti. 2014. "Manajemen Ekstrakurikuler Dalam Meningkatkan Mutu Sekolah." Al-Fikrah: Jurnal Kependidikan Islam IAIN Sulthan Thaha Saifuddin 5(11):150-61. 